\title{
Geologic Cross Section, Gas Desorption, and Other Data From Four Wells Drilled for Alaska Rural Energy Project, Wainwright, Alaska, Coalbed Methane Project, 2007-2009
}

Arthur C. Clark1', Stephen B. Roberts ${ }^{2}$ and Peter D. Warwick

U.S. Geological Survey, PO Box 25046, MS 939, Denver Federal Center, Denver, CO 80225

U.S. Geological Survey, Denver, CO retired

${ }^{3}$ U.S. Geological Survey, 956 National Center, 12201 Sunrise Valley Drive, Reston, VA 20192

Energy costs in rural Alaskan communities are substantial. Diesel fuel which must be delivered by barge or plane is used for local power generation in most off-grid communities. In addition to high costs incurred for the purchase and transport of the fuel, the transport, transfer, and storage of fuel products pose significant difficulties in logistically challenging and environmentally sensitive areas. The Alaska Rural Energy Project (AREP) is a collaborative effort between the United States Geological Survey (USGS) and the Bureau of Land Management Alaska State Office along with State, local, and private partners. The project is designed to identify and evaluate shallow $(<3,000 \mathrm{ft})$ subsurface resources such as coalbed methane (CBM) and geothermal in the vicinity of rural Alaskan communities where these resources have the potential to serve as local-use power alternatives.

The AREP, in cooperation with the North Slope Borough, the Arctic Slope Regional Corporation, and the Olgoonik Corporation, drilled and tested a 1,613- $\mathrm{ft}$ continuous core hole in Wainwright, Alaska, during the summer of 2007 to determine whether CBM represents a viable source of energy for the community. Although numerous gas-bearing coal beds wereencountered, most are contained within the zone of permafrost that underlies the area to a depth of approximately $1,000 \mathrm{ft}$. Because the effective permeability of permafrost is near zero, the chances of producing gas from these beds are highly unlikely. $A 7.5$-ft-thick gas-bearing coal bed, informally named the Wainwright coal bed, was encounter sub-permafrost at a depth of $1,242 \mathrm{ft}$. Additional drilling and testing conducted during the summers of 2008 and 2009 indicated that the coal bed extended throughout the area outlined by the drill holes, which presently is limited to the access provided by the existing road system. These tests also confirmed the gas content of the coal reservoir within this area. If producible, the Wainwright coal bed contains sufficient gas to serve as a long-term source of energy for the community.

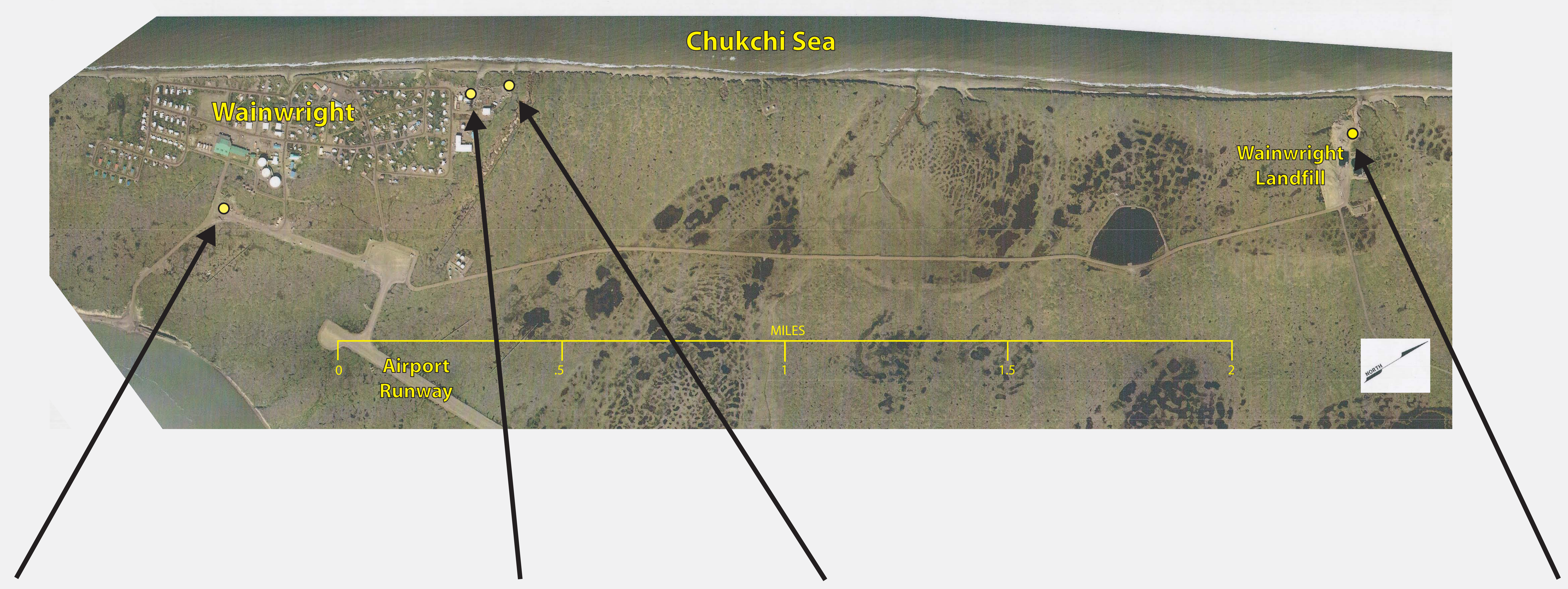

W-10-09 (Wainwright-10)

$N 70^{\circ} 38.58^{\prime \prime}$
$W 160^{\circ} 011^{\prime \prime} 456^{\prime \prime}$

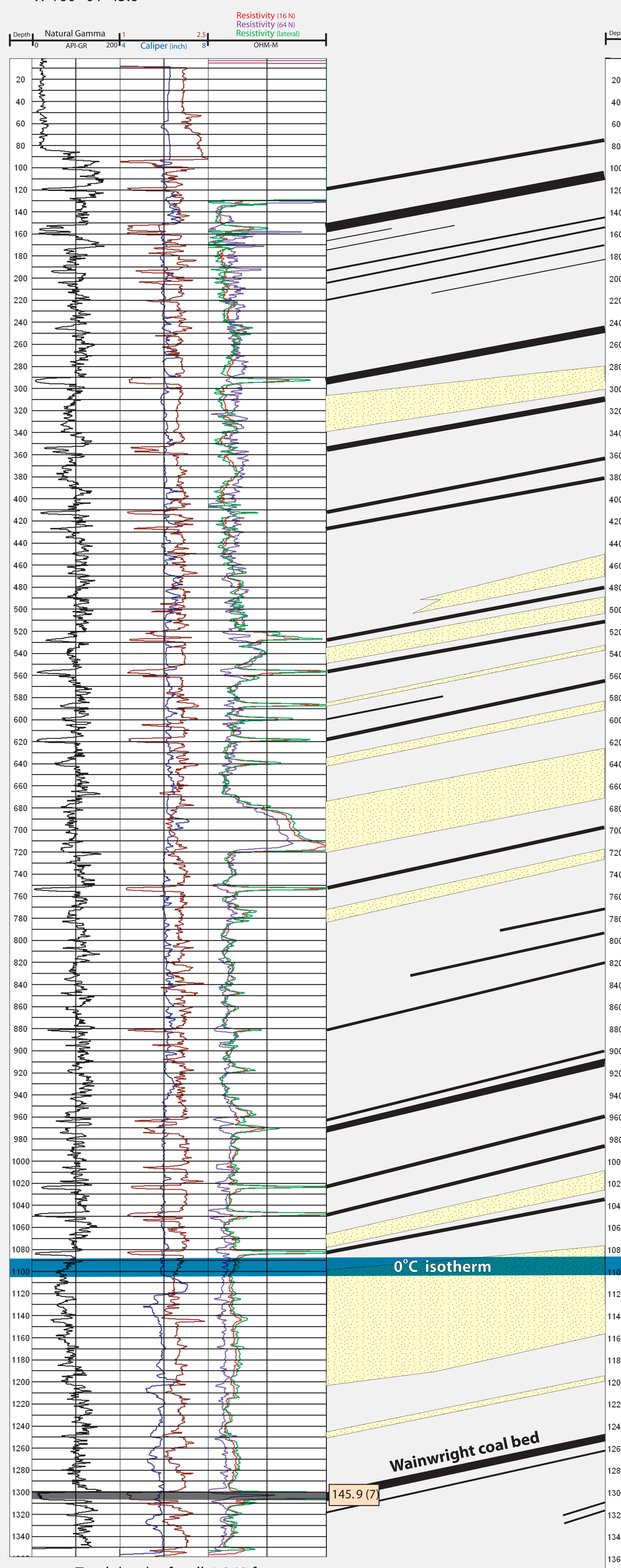

Total depth of well: 1,360
W-OC1-08 (Wainwright-8) $N 70^{\circ} 38^{\circ} 37.17^{\prime \prime}$
$W 160^{\circ} 01^{\prime} 25.9$

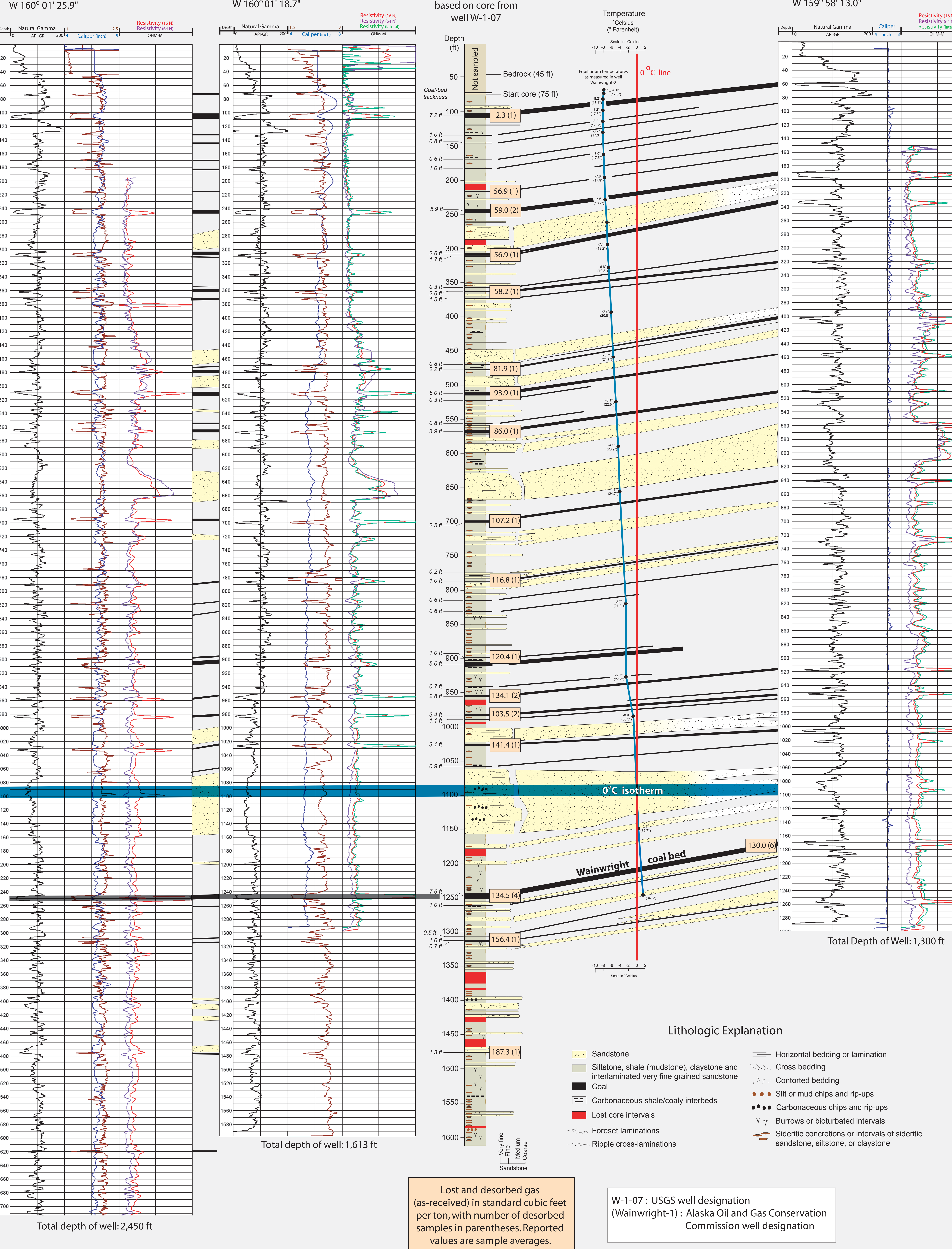

$W-1-07($ Wain
N $70^{\circ} 38^{\prime} 41.0^{\prime \prime}$
$W 160^{\circ} 01^{\prime} 18.7^{\prime \prime}$

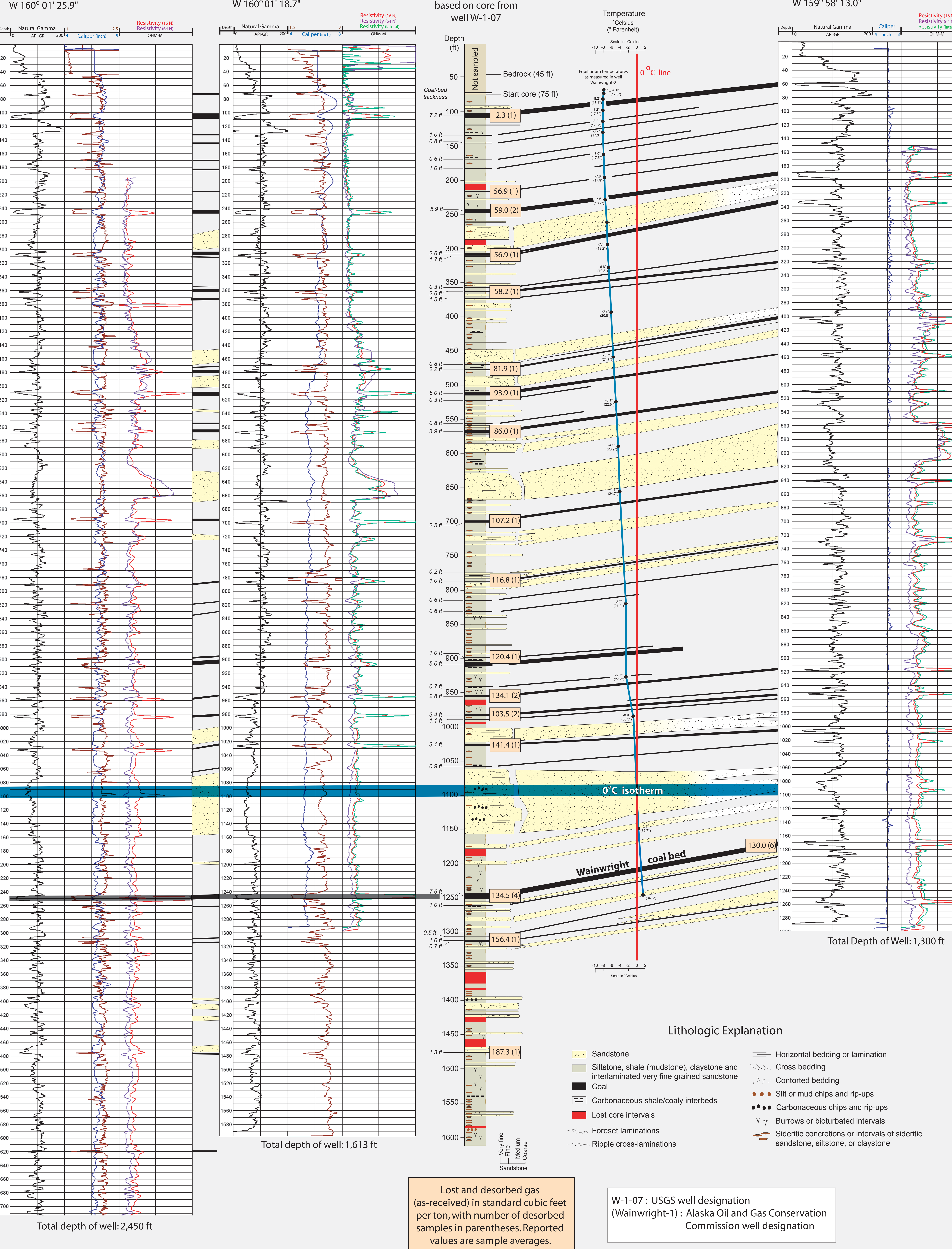

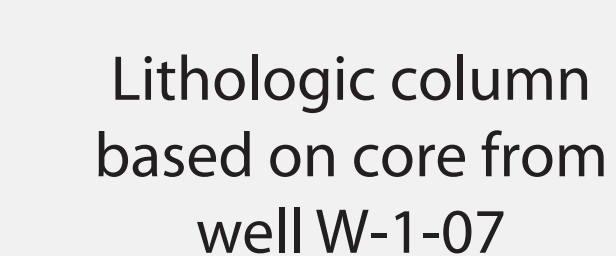

W-9-09 (Wart $\begin{array}{ll}N 70^{\circ} 39^{\prime} 58.6^{\prime \prime} \\ W \\ W & 150^{\circ} 58^{\prime} 130^{\circ}\end{array}$ 